\title{
DINAMIKA WAKTU TANAM PADI DI LAHAN RAWA LEBAK PULAU KALIMANTAN
}

\section{Dynamic of Paddy Cropping Time on Fresh Water Swampland in Kalimantan Island}

\author{
Nur Wakhid ${ }^{1 *}$ dan Haris Syahbuddin ${ }^{2}$ \\ ${ }^{1}$ Balai Penelitian Pertanian Lahan Rawa, \\ Jl. Kebun Karet, Loktabat Utara, Banjarbaru, Indonesia \\ ${ }^{2}$ Balai Besar Pengkajian dan Pengembangan Teknologi Pertanian, \\ Jl. Tentara Pelajar No. 10, Bogor, Indonesia \\ *Alamat Korespondensi : n_wakhid@yahoo.com
}

\begin{abstract}
ABSTRAK
Lahan rawa lebak merupakan salah satu lahan yang cukup potensial untuk pengembangan pertanian. Salah satu faktor penentu kebehasilan budidaya pertanian di lahan rawa lebak adalah waktu tanam. Pergeseran waktu tanam saat ini berubah sangat dinamik di tengah perubahan iklim yang tidak menentu. Oleh karena itu, analisis tentang waktu tanam menjadi sangat penting untuk dilakukan, termasuk waktu tanam padi di sawah lahan rawa lebak. Tujuan penelitian ini adalah untuk menganalisis dinamika waktu tanam padi di lahan rawa lebak Pulau Kalimantan sehubungan dengan dinamika perubahan iklim. Waktu tanam padi di sawah lahan rawa lebak Pulau Kalimantan menunjukkan dinamika yang berbeda, dimana waktu tanam dominan di Kalimantan Selatan dan Kalimantan Timur tejadi sekitar bulan Juni-Juli, sedangkan di Kalimantan Barat dan Kalimantan Tengah pada bulan Oktober-November. Sawah lahan rawa lebak menunjukkan adaptasi yang baik di tengah perubahan iklim dimana waktu tanam padi hanya sedikit bergeser dalam kurun waktu 10 tahun.
\end{abstract}

Kata kunci: lahan potensial, pertanian, perubahan iklim, sawah

\section{ABSTRACT}

Fresh water swampland is a potential area for agricultural development. One of crucial indicator for agricultural cultivation in fresh water swampland is planting time. At present, the shift of planting time is changing dynamically due to uncertainty of climate change. Therefore, an analysis of planting time is very important to observe, including the time of planting in the swampy rice fields. The objective of this study was to analysis the dynamics of rice planting time in fresh water swampland field areas in Kalimantan Island. The paddy cropping time in the swampy rice fields of kalimantan Island showed various dynamics, where the dominant planting time in South Kalimantan and East Kalimantan occurred around June-July, while in West Kalimantan and Central Kalimantan in October-November. The fresh water swampland field showed a good adaptation under climate change condition where paddy cropping time had only shifted slightly within 10 years.

Keywords: potential land, agriculture, climate change, rice field

\section{PENDAHULUAN}

Lahan rawa di Indonesia terdapat sekitar 33,4 juta hektar dan sebanyak 9,53 juta ha diantaranya dinyatakan sesuai untuk kegiatan budidaya pertanian (Haryono, 2012). Salah satu lahan rawa terluas dan potensial untuk dikembangkan terdapat di pulau Kalimantan, khususnya Propinsi Kalimantan Selatan (Ritung, 2011).
Berdasarkan pengaruh pasang surut, lahan rawa dibagi menjadi 2 zona yaitu lahan rawa pasang surut dan non pasang surut atau rawa lebak. Lahan rawa pasang surut dipengaruhi oleh gerakan air pasang surut laut dan atau sungai, baik langsung maupun tidak langsung, sedangkan rawa lebak lebih dipengaruhi oleh air setempat (water logging) dan air kiriman dari kawasan hulu. 
Lahan rawa lebak merupakan salah satu lahan yang cukup potensial untuk pengembangan pertanian selain rawa pasang surut (Wakhid dan Syahbuddin, 2018). Lahan rawa lebak terbentuk pada dataran rendah diantara sungai maupun diantara bukit, sehingga kondisi tanahnya biasanya dapat dikategorikan tanah yang subur (Noor, 2007). Rawa disebut sebagai lebak dengan 2 kriteria yaitu terletak jauh dari pantai, dan tergenangi air akibat luapan air sungai dan/atau air hujan yang menggenang secara periodik atau menerus (PP RI, 2013). Berdasarkan kondisi topografi yang memunculkan perbedaan tinggi dan lama genangan, lahan rawa lebak terdiri atas lebak dangkal, yaitu lahan yang tergenang dengan tinggi muka air $<50 \mathrm{~cm}$ selama kurang dari 3 bulan, lebak tengahan, yaitu lahan yang tergenang dengan tinggi muka air 50-100 cm selama 3-6 bulan, dan lebak dalam, yaitu lahan yang tergenang dengan tinggi muka air $>100 \mathrm{~cm}$ selama 6 bulan atau lebih (BBSDLP, 2006). Luas lahan rawa lebak diperkirakan mencapai 25,21 juta hektar atau 74 persen dari luas total lahan rawa di Indonesia (Ritung et al., 2015).

Pemanfaatan lahan rawa lebak untuk usaha pertanian merupakan salah satu alternatif yang dapat diambil dalam upaya memenuhi kebutuhan pangan yang terus meningkat. Hal ini dilakukan mengingat selain permintaan akan kebutuhan pangan yang terus meningkat sejalan dengan pertambahan jumlah penduduk, juga karena telah terjadi peralihan fungsi lahan subur yang selama ini digunakan sebagai areal pertanian tanaman pangan dan pelandaian produksi pada lahan yang masih tersisa (Kusnadi et al., 2011). Konversi lahan sawah menjadi lahan non sawah di Pulau Jawa mencapai 100.000 hektare per tahun. Di sisi lain, kebutuhan pangan rakyat Indonesia terutama beras diperkirakan meningkat 1-2 persen setiap tahunnya (Haryono, 2012). Disamping itu, Indonesia selama 15 tahun sejak tahun 2000 sampai tahun 2015 selalu impor beras sebanyak 15,39 juta ton (Puspitasari et al., 2019). Padahal, potensi lahan rawa lebak di Indonesia masih cukup besar. Dari 13,28 juta ha lahan rawa lebak menurut Widjaja et al. (1992) 10,18 juta ha berpotensi untuk dijadikan lahan pertanian. Akan tetapi hanya 1,55 juta ha diantaranya yang dibuka dan yang dimanfaatkan untuk pertanian hanya sekitar 0,729 juta ha (Direktorat Perluasan Areal Kementerian Pertanian, 2004). Rata-rata produksi di sawah lahan rawa lebak mencapai sekitar 4 ton GKG/hektare (Haryono et al., 2012).

Salah satu faktor penentu keberhasilan budidaya pertanian di lahan rawa lebak adalah waktu tanam. Penentuan waktu tanam tanaman pangan terutama padi mempunyai peranan yang sangat penting pada produksi akhir hasil pertanian 
(Runtunuwu dan Syahbuddin, 2007; Runtunuwu et al., 2011). Waktu tanam yang tidak tepat akan mengakibatkan produksi menjadi rendah, di samping potensi terkena hama penyakit semakin meningkat (Irianto et al., 2000). Saat ini pergeseran waktu tanam berubah sangat dinamik di tengah perubahan iklim yang tidak menentu (Runtunuwu et al., 2012; Runtunuwu et al., 2013). Oleh karena itu, analisis tentang waktu tanam menjadi sangat penting untuk dilakukan, termasuk waktu tanam padi di sawah lahan rawa lebak. Tujuan makalah ini adalah untuk menganalisis dinamika waktu tanam padi di lahan rawa lebak Pulau Kalimantan sehubungan dengan dinamika perubahan iklim. Diharapkan lahan rawa dapat dijadikan salah satu alternatif lumbung pangan menghadap perubahan iklim di Indonesia.

\section{METODE PENELITIAN}

\section{Pengumpulan data}

Analisis waktu tanam dilakukan di lahan rawa Pulau Kalimantan pada tahun 2011 sampai tahun 2012. Analisis waktu dan luas tanam dilakukan hingga tingkat kecamatan melalui pendekatan desk study. Data yang dikumpulkan terdiri dari: (i) Data luas tanam 10 tahun 2000-2010 dari Badan Pusat Statistik (BPS); (ii) Data primer hasil wawancara dengan petani di lahan rawa (dengan pertanyaan utama meliputi tinggi muka air atau genangan, puncak tanggal tanam, rotasi tanaman dan intensitas tanam; (iii) Data curah hujan harian selama 10 tahun dari 2001-2010 lahan rawal lebak pulau Kalimantan dari stasiun iklim Badan Meteorologi, Klimatologi dan Geofisika (BMKG), Kementerian Pekerjaan Umum (PU) dan Balai Proteksi Tanaman Pangan dan Hortikultura (BPTPH) di Pulau Kalimantan; dan (iv) Data sifat hujan musim tanam 2011/2012 dari BMKG.

\section{Analisis Data}

Penelitian dilakukan dalam 3 tahap (i) Analisis data luas sawah di Lahan rawa lebak Pulau Kalimantan; (ii) Analisis waktu tanam padi berdasarkan luas tanam di sawah Lahan rawa lebak Pulau Kalimantan; dan (iii) Analisis waktu tanam padi pada tahun dan kondisi iklim yang berbeda.

Analisis waktu tanam menggunakan data dasarian atau 10 harian, dimulai dari bulan Januari sampai Desember dengan total 36 dasarian (Runtunuwu et al., 2013). Data dasarian digunakan untuk penetapan waktu tanam karena mengikuti rentang waktu dasarian data curah hujan yang berkaitan erat dengan musim tanam. Permulaan musim hujan ditandai dengan jumlah curah hujan dalam satu dasarian sama atau lebih besar dari $50 \mathrm{~mm}$ dan diikuti oleh dua dasarian berikutnya, Sedangkan musim kemarau ditandai dengan jumlah curah dalam satu dasarian kurang dari $50 \mathrm{~mm}$ dan diikuti oleh dua 
dasarian berikutnya (BMKG, 2011). Kriteria waktu tanam (awal musim hujan) ini dikelompokkan berdasarkan pola sirkulasi dinamika atmosfer di wilayah tropis. Di mana pola ITCZ (Inter Tropical Convergence Zone) wilayah tropis terbagi atas dua alur waktu. Pada saat matahari berada lebih dekat ke bumi bagian Utara (Juni - September), maka kumpulan uap air (ITCZ) bergerak ke bumi bagian Selatan, dan melintasi equator. Itulah sebabnya pada bulan Oktober, sebagian besar wilayah Indonesia mulai memasuki musim hujan. Akan tetapi sebaliknya, ketika posisi matahari lebih dekat ke bumi bagian Selatan (Desember - Februari), maka ITCZ akan bergerak ke bumi bagian Utara, dan menjadikan wilayah Indonesia mulai memasuki musim kering pada bulan April. Kriteria musim tanam dimulai dari September I/II sampai dengan Agustus II/III disajikan pada Tabel 1.

\section{HASIL DAN PEMBAHASAN}

\section{Luas Lahan Sawah di Rawa lebak Pulau Kalimantan}

Luas sawah lebak terluas di Kalimantan dimiliki oleh Provinsi Kalimantan Selatan, diikuti Provinsi Kalimantan Barat. Tercatat sawah lebak di Kalimantan Selatan mencapai 66.649 ha dengan luas sawah rawa lebak terluas terdapat di Kecamatan Candilaras Utara,
Kabupaten Tapin. Luas sawah lebak berikutnya adalah Kalimantan Barat seluas 7.135 ha, Kalimantan Tengah seluas 6.066 ha, dan paling kecil adalah Kalimantan Timur seluas 950 ha. Luas sawah lebak disajikan dalam Gambar 1.

Di Provinsi Kalimantan Selatan, lahan rawa rawa lebak tersebar di Kabupaten Balangan, Hulu Sungai Selatan, Hulu Sungai Tengah, Hulu Sungai Utara, dan Tabalong. Meskipun dari aspek kesuburan tanah rawa lebak tidak memiliki masalah, sebab sebagian besar merupakan daerah endapan banjir dari daerah hulu yang relatif subur, hambatan ketersediaan air menjadikan lahan ini tidak terlalu banyak tergarap/dibuka untuk areal persawahan. Hambatan ketersediaan air tersebut tidak saja terkait dengan kekeringan pada saat kemarau panjang, tetapi juga aspek keberlimpahan air yang dapat menyebabkan lahan tergenang cukup lama (sekitar 1-3 bulan untuk rawa lebak dangkal dan tengahan, dan $>6$ bulan untuk lebak dalam). Seperti halnya juga di Kalimantan Selatan, di Provinsi Kalimantan Tengah, lahan rawa lebak yang digunakan untuk persawahan hanya sekitar 6000 ha saja. Begitu pun di Provinsi Kalimantan Barat dan kalimantan Timur, dimana areal persawahan di lahan rawa lebak hanya berkisar 900 sampai dengan 7000 ha saja (Tabel 2). 
Tabel 1. Kelompok Kalender Awal Tanam Padi Lahan Rawa

\begin{tabular}{llll}
\hline Kelompok & Kriteria waktu tanam & Kelompok & Kriteria waktu tanam \\
\hline I & Sep I - II & X & Mar I - II \\
II & Sep III - Okt I & XI & Mar III - Apr I \\
III & Okt II - III & XII & Apr II - III \\
IV & Nov I - II & XIII & Mei I - II \\
V & Nov III - Des I & XIV & Mei III - Jun I \\
VI & Des II - III & XV & Jun II - III \\
VII & Jan I - II & XVI & Jul I - II \\
VIII & Jan III - Feb I & XVII & Jul III - Ags I \\
IX & Feb II - III & XVIII & Ags II - III
\end{tabular}

Sumber : Wakhid et al (2015)

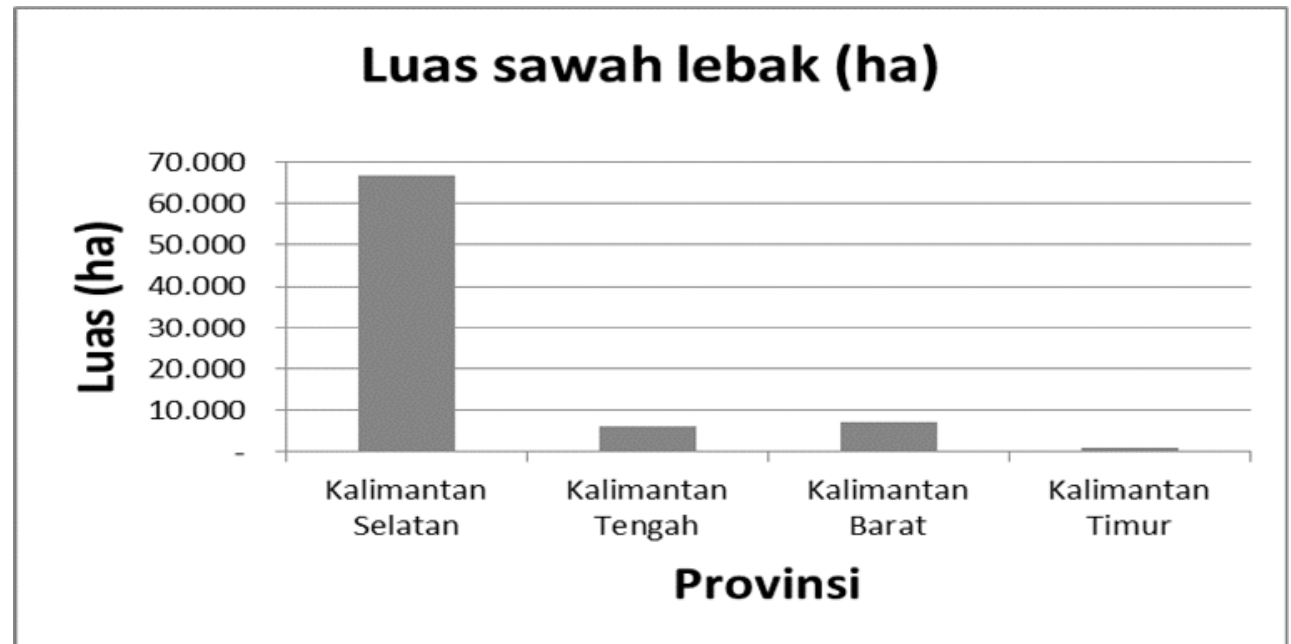

Gambar 1. Luas sawah pada Ekosistem Rawa Lebak Seluruh Provinsi di Pulau Kalimantan. Sumber: Analisis data BPS (2011).

Tabel 2. Luas Lahan Sawah Terluas pada Ekosistem Rawa Pasang Surut, Lebak dan Polder lainnya seluruh Provinsi di Pulau Kalimantan

\begin{tabular}{cc}
\hline Propinsi & Lebak \\
\hline Kalimantan Barat & 1.548 ha \\
Kabupaten & Landak \\
Kecamatan & Mempawah Hulu \\
\hline Kalimantan Selatan & 5.168 ha \\
Kabupaten & Tapin \\
Kecamatan & Candi Laras Utara \\
\hline Kalimantan Tengah & 899 ha \\
Kabupaten & Barito Selatan \\
Kecamatan & Dusun Hilir \\
\hline Kalimantan Timur & 782 ha \\
Kabupaten & Kutai \\
Kecamatan & Kota Bangun \\
\hline
\end{tabular}

Sumber: BPS (2011). 


\section{Realisasi Waktu Tanam Padi Di Sawah Lahan Rawa Lebak}

Realisasi waktu tanam padi sawah rawa lebak di Pulau Kalimantan menunjukkan pola yang cukup berbeda. Waktu tanam puncak di Propinsi Kalimantan Selatan mirip dengan pola di Kalimantan Timur dimana realisasi waktu tanam terbanyak terjadi pada kisaran dasarian 16-22 atau sekitar bulan Juni-Juli. Pola ini berlawanan dengan waktu tanam di Propinsi Kalimantan Barat dan Kalimantan Tengah, dimana waktu tanam dominan terjadi pada dasarian 30-33 atau sekitar bulan Oktober-November. Pada dasarnya realisasi tanam petani di sawah rawa lebak terjadi setelah lahan surut atau pada musim kemarau, kecuali di lebak dangkal (Gambar 2).

Waktu tanam di Kalimantan Selatan dan Kalimantan Timur terjadi pada bulan kemarau dimana genangan air sudah sangat berkurang di lahan. Sedangkan di Kalimantan Barat dan Kalimantan Tengah waktu tanam dominan terjadi pada awal musim hujan dimana kemungkinan tinggi genangan di lahan lebih tinggi walupun belum terlalu dalam. Hal ini terjadi karena luas lahan rawa lebak yang ada di Kalimantan Selatan dan Timur kemungkinan di dominasi oleh lahan lebak tengahan maupun dalam, sedangkan di Kalimantan Barat dan Tengah didominasi oleh lebak dangkal.
Waktu tanam di Kalimantan Barat dan Kalimantan Tengah berkembang di musim hujan, kemungkinan juga dipengaruhi oleh drainase yang lebih bagus dibanding Kalimantan Selatan atau Timur. Dimana saat musim penghujan, rawa lebak di Kalimantan Selatan masih banyak yang tergenang sehingga penanaman padi dominan dilakukan pada musim kemarau. Pola tanam di masing-masing propinsi di Pulau Kalimantan juga berkaitan erat dengan sifat hujan (ZOM BMKG) di tempat tersebut. Kondisi iklim di Indonesia dipengaruhi oleh fenomena El Nino/La Nina yang bersumber dari wilayah timur Indonesia (Ekuator Pasifik Tengah/Nino34) dan Dipole Mode yang bersumber dari wilayah barat Indonesia (Samudera Hindia barat Sumatera hingga timur Afrika). Disamping itu juga dipengaruhi oleh fenomena regional, seperti sirkulasi monsun Asia-Australia, daerah pertemuan angin antar tropis atau Inter Tropical Convergence Zone (ITCZ) yang merupakan daerah pertumbuhan awan, serta kondisi suhu permukaan laut sekitar wilayah Indonesia. Pulau Kalimantan yang meliputi 4 propinsi terdiri dari 22 Zona Musim (ZOM) yaitu nomor 264 - 285. Awal musim hujan 2011/2012 pada 22 Zona Musim (ZOM) di Kalimantan, diprakirakan berkisar pada bulan Oktober 2011. Khusus untuk daerah Kalimantan Barat masuk Non Zona Musim (Non ZOM), dimana daerah 
tersebut pada umumnya tidak mempunyai perbedaan yang jelas antara periode musim hujan dan musim kemarau, dalam hal ini daerah yang sepanjang tahun curah hujannya tinggi atau rendah. Berdasarkan data prakiraan hujan BMKG Pontianak tahun 2011/2012, sebagian besar wilayah Kalimantan Barat mempunyai sifat hujan normal kecuali kota Singkawang yang mempunyai sifat hujan atas normal (BMKG, 2011).

Metode tanam dan varietas juga berpengaruh pada waktu tanam keseluruhan, dimana proses awal tanam yang terjadi tergantung varietas padi tersebut. Di rawa lebak biasanya dikenal 2 macam padi yaitu rintak dan surung. Padi rintak yaitu padi yang ditanam pada musim kemaru. Biasanya jenis padi yang ditanam adalah padi unggul, sedangkan padi surung adalah jenis padi lokal yang dapat bertahan pada genangan air.

\section{Waktu Tanam Padi pada tahun dan Kondisi Iklim yang berbeda}

Pola waktu tanam di lahan rawa lebak Pulau Kalimantan tidak banyak berubah dari tahun 2000-2010, walaupun kondisi iklim yang berbeda selama 10 tahun tersebut. Gambar 3 menunjukkan bahwa lahan rawa lebak memiliki tingkat kekukuhan yang tinggi terhadap perubahan iklim. Pola realisasi tanam hanya mengalami pergeseran sedikit sekali ketika terjadi El Nino maupun La Nina. Meskipun secara spesifik dapat dikatakan bahwa, sebagian lahan rawa lebak tengahan dan dalam akan mengalami perluasan areal pemanfaatannya. Akan tetapi perluasan areal ini adalah sebagai kompensasi dari tidak dapat dimanfaatkannya lebak dangkal untuk usaha tani padi sawah.

Tinggi genangan secara tegas mempengaruhi pola tanam di lahan rawa lebak. Pada musim hujan tinggi genangan menjadi faktor penentu penanaman padi. Sementara pada musim kering tinggi muka air tanah yang menjadi pembatas (Wakhid et al., 2015). Secara umum tinggi genangan optimal untuk tanaman padi di sawah $<24$ $\mathrm{cm}$. Pada musim hujan genangan air yang dapat ditoleransi padi sekitar $35 \mathrm{~cm}$ dari permukaan tanah. Pada padi lokal, mereka mempunyai mekanisme mempertahankan diri dari genangan air dengan memanjangkan batang melewati permukaan air. Sementara pada padi unggul lahan rawa, rendaman air di atas $35 \mathrm{~cm}$ itu dapat ditoleransi bila lama genangan tidak melebihi 14 hari. Sementara tinggi muka air tanah yang optimal untuk tanaman padi ialah $<40 \mathrm{~cm}$. Pada kondisi itu perakaran tanaman padi masih dapat menjangkau air untuk memenuhi kebutuhan hidupnya. Di saat musim kering, tinggi muka air tanah turun atau lebih dalam dari $40 \mathrm{~cm}$. Saat itu perakaran padi tidak lagi dapat menjangkau air sehingga menjadi faktor pembatas. 


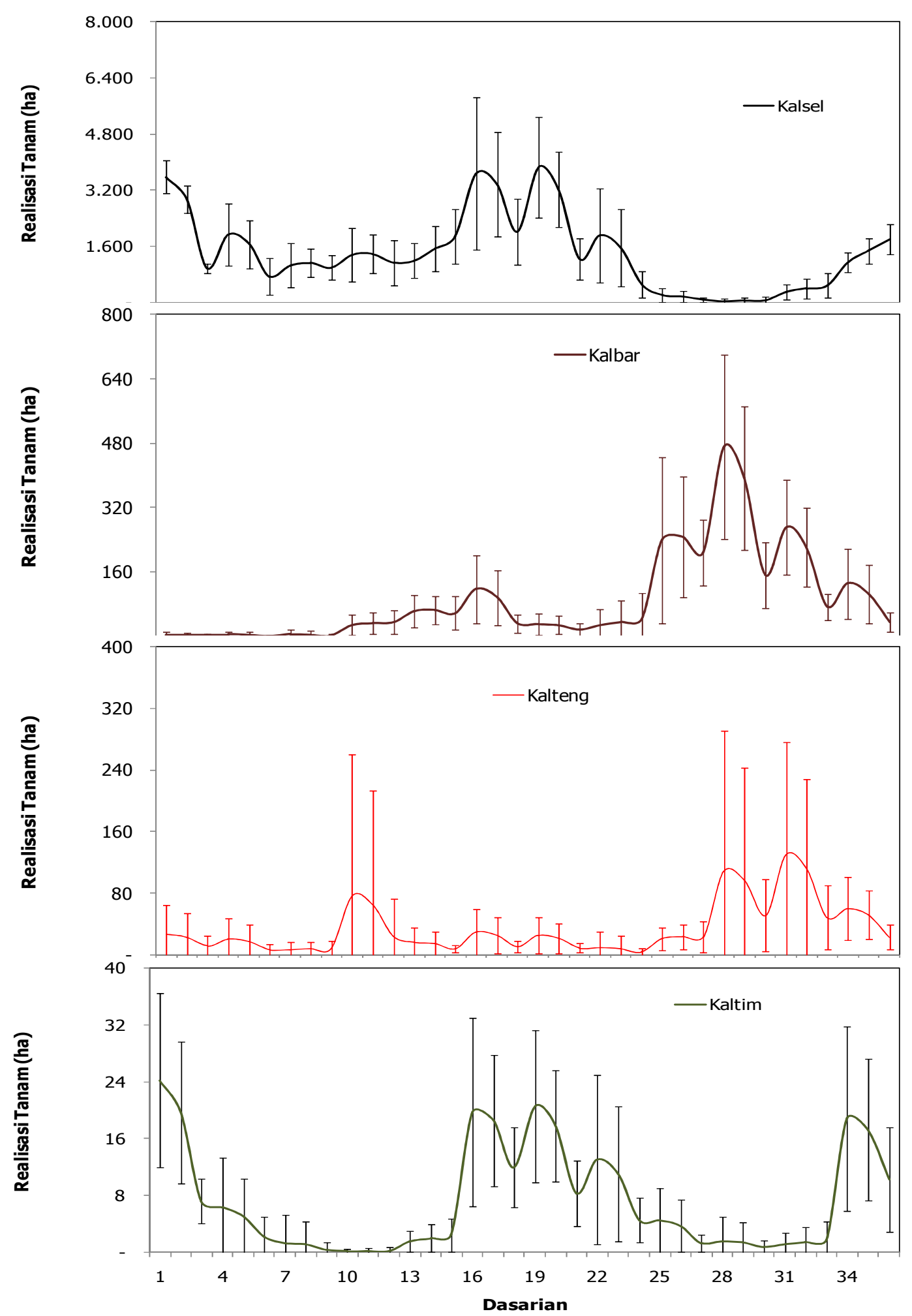

Gambar 2. Pola Realisasi Tanam Dasarian Padi pada Lahan Sawah Lebak di Kalimantan, Periode 2000-2010. 

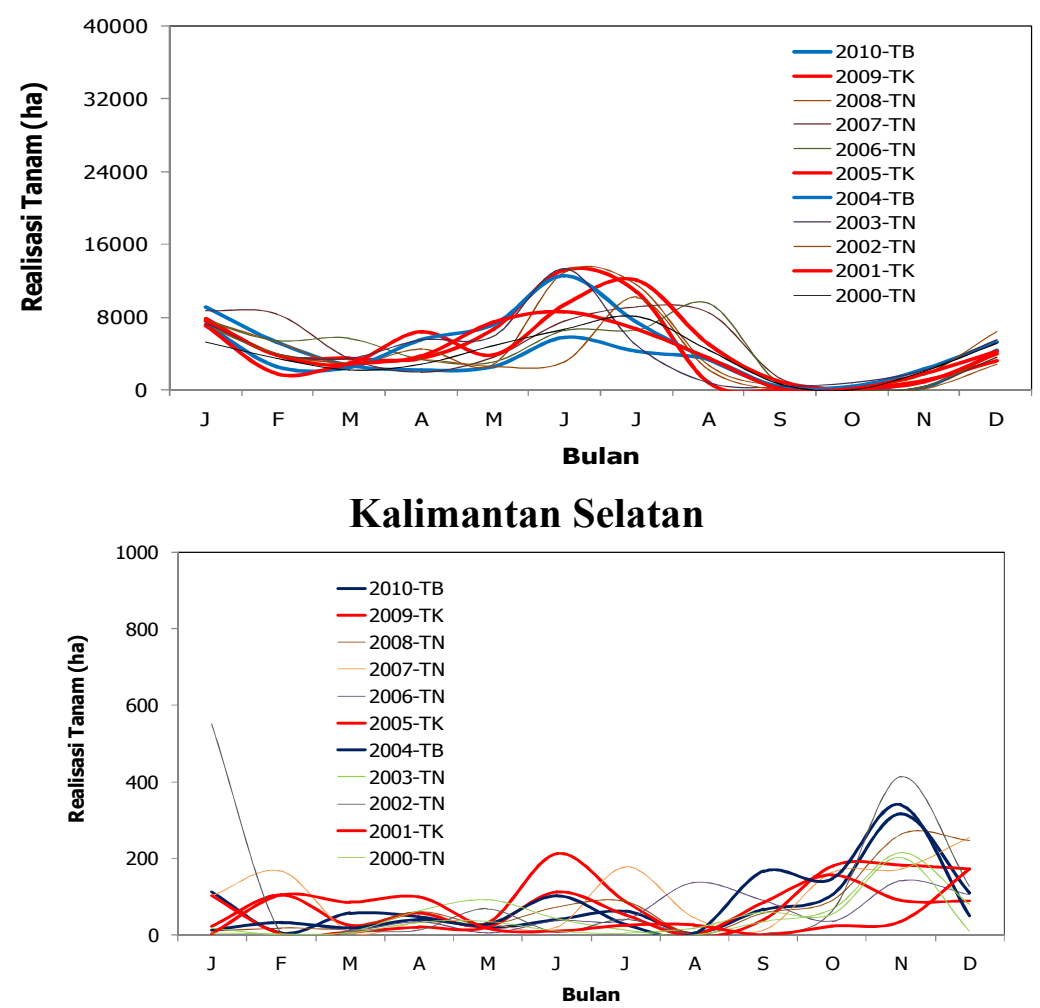

\section{Kalimantan Tengah}
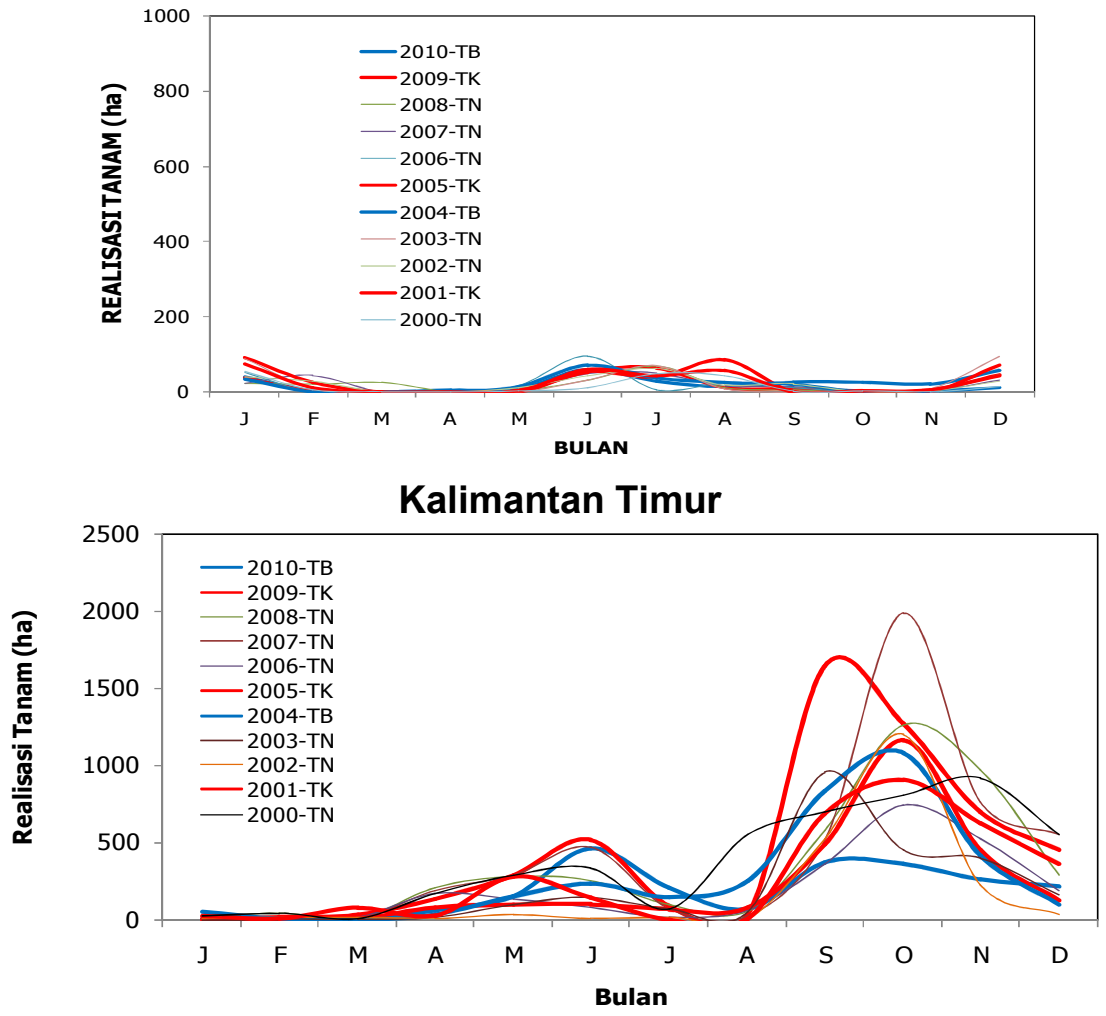

Kalimantan Barat

Keterangan: $\mathrm{TB}=$ Tahun Basah, $\mathrm{TK}=$ Tahun Kering, $\mathrm{TN}=$ Tahun Normal Gambar 3. Pola Realisasi Tanam Dasarian Padi pada Lahan Sawah Lebak di Pulau Kalimantan, periode 2000-2010. 
Berdasarkan Gambar 2. dan 3. juga dapat dilihat bahwa sebagian besar pola tanam yang masih dilakukan hanya satu kali saja dalam satu tahun. Oleh karena itu lahan rawa lebak seharusnya masih dapat ditingkatkan produksinya, minimal dengan menambah indeks pertanaman menjadi dua kali dalam 1 tahun. Disamping itu lahan rawa lebak juga mempunyai keunggulan dalam adaptasi terhadap perubahan iklim.

\section{KESIMPULAN}

Waktu tanam di sawah lahan rawa lebak Pulau Kalimantan menunjukkan dinamika yang berbeda, dimana waktu tanam dominan di Kalimantan selatan dan Timur tejadi sekitar bulan Juni-Juli, sedangkan di Kalimantan Barat dan Tengah pada bulan Oktober-November. Realisasi luas tanam puncak di lahan rawa lebak mencapai sekitar 82 ribu ha di Kalimantan Selatan, 895 ha di Kalimantan Timur, 6.400 ha di Kalimantan Tengah, dan 8.400 di Kalimantan Barat. Sawah lahan rawa lebak menunjukkan adaptasi yang baik di tengah perubahan iklim dimana waktu tanam padi hanya sedikit bergeser dalam kurun waktu 10 tahun.

\section{UCAPAN TERIMA KASIH}

Penulis mengucapkan terima kasih kepada rekan-rekan peneliti dan teknisi di Balai Penelitian Pertanian Lahan Rawa yang telah memberi dukungan terhadap pelaksanaan penelitian ini dari awal sampai akhir.

\section{DAFTAR PUSTAKA}

BBSDLP. 2006. Karakteristik dan Pengelolaan Lahan Rawa. Bogor. Balai Besar Penelitian dan Pengembangan Sumberdaya Lahan Pertanian (BBSDLP). $297 \mathrm{hlm}$.

BMKG. 2011. Sifat Musim Hujan 20112012. Jakarta. BMKG.

BPS. 2011. Kalimantan Dalam Angka. BPS Kalimantan.

Direktorat Perluasan Areal Kementerian Pertanian. 2004. Strategi dan langkah operasional program penumbuhan kantong penyangga padi di lahan lebak. Makalah disajikan pada Pertemuan Nasional Program Penumbuhan Kantong Penyangga Padi di Lahan Lebak. Palembang, 22 - 24 April 2004.

Haryono. 2012. Lahan rawa lumbung pangan masa depan Indonesia. IAARD Press. Jakarta.

Haryono, M. Noor, H. Syahbuddin, dan M. Sarwani. 2012. Lahan Rawa: Penelitian dan Pengembangan. IAARD Press. Jakarta.

Irianto, G., L. I. Amien, dan E. Surmaini. 2000. Keragaman Iklim Sebagai Peluang Diversifikasi sumber daya lahan Indonesia. Pusat Penelitian Tanah dan Agroklimat. Badan Penelitian dan Pengembangan Pertanian. Bogor.

Kusnadi, N., N. Tinaprillia, S. H. Susilowati, dan A. Purwoto. 2011. Analisis efisiensi usahatani padi di beberapa sentra produksi padi di Indonesia. Jurnal Agroekonomi, 29 (1): $25-48$. 
Noor, M. 2007. Rawa Lebak, Ekologi Pemanfaatan, dan Pengembangannya. Rajawali Pers. Jakarta.

PP RI. 2013. Peraturan Pemerintah (PP) Republik Indonesia nomor 73 tahun 2013 tentang rawa. Pemerintah Republik Indonesia.

Puspitasari, N., L. R. Indrawati, dan S. N. Sarfiah. 2019. Analisis Pengaruh Harga Beras, Cadangan Devisa, dan Rata-Rata Konsumsi Beras Per Kapita Seminggu Terhadap Impor Beras di Indonesia Tahun 2008- 2017. DINAMIC: Directory Journal of Economi, 1(1): 55 - 67.

Ritung, S. 2011. Karakteristik dan sebaran lahan sawah di Indonesia. Hlm 83-98. Dalam. Prossiding Seminar Nasional Teknologi Pemupukan dan Pemulihan lahan Terdegradasi. Balai Penelitian dan Pengembangan Sumberdaya Lahan Pertanian. Bogor.

Ritung S., E. Suryani, D. Subardja Sukarman, K. Nugroho, Suparto, Hikmatullah, A. Mulyani, C. Tafakresnanto, Y. Sulaeman, R. E. Subandiono, Wahyunto, Ponidi, N. Prasodjo, U. Suryana, H. Hidayat, A. Priyono, dan W. Supriatna. 2015. Sumber daya lahan pertanian Indonesia, luas, penyebaran dan potensi ketersediaan. IAARD Press. Jakarta.

Runtunuwu E., dan Syahbuddin H. 2007. Perubahan Pola Curah Hujan dan Dampaknya Terhadap Periode Masa Tanam. Jurnal Tanah dan Iklim, 6: 1 -12 .

Runtunuwu E., Syahbuddin H., dan Nugroho W. T. 2011. Delinasi Kalender Tanam Tanaman Padi Sawah Untuk Antisipasi Anomali Iklim Mendukung Program Peningkatan produksi Beras
Nasional. Jurnal Pangan, 20(4): 341 -356 .

Runtunuwu, E., H. Syahbuddin dan F. Ramadhani. 2012. Keragaman Waktu Tanam Tanaman Padi di Pulau Kalimantan. Jurnal Agronomi, 40(1): 8-14.

Runtunuwu E., H. Syahbuddin, dan W. T. Nugroho. 2013a. Dinamika Kalender Tanam Padi di Sulawesi. Jurnal pangan, 21(2): 113-124.

Runtunuwu, E., H. Syahbuddin, F. Ramadhani, Y. Apriyana, K. Sari, dan W. T. Nugroho. 2013b. Tinjauan Waktu Tanam Tanaman Pangan di Wilayah Timur Indonesia (Review of Food Crop Planting Time in Eastern Indonesia). Jurnal Pangan, 22(1): 1 10.

Wakhid, N., H. Syahbuddin, I. Khairullah. L. Indrayati, D. Cahyana, Mawardi, M. Noor, K. Anwar, M. Alwi, dan A. Hairani. 2015. Peta Kalender Tanam Padi Lahan Rawa Lebak di Kalimantan Selatan. Jurnal tanah dan iklim, 39(1): 1410 - 7244.

Wakhid, N., dan H. Syahbuddin. 2018. Waktu Tanam Padi Sawah Rawa Pasang Surut Pulau Kalimantan di Tengah Perubahan Iklim. Jurnal Agrin, 22(2): 145 - 159.

Widjaja, A, I. P. G., Nugroho, D. Ardi dan AS. Karama. 1992. Sumber daya lahan pasng surut, rawa dan pantai: potensi, keterbatasan dan pemanfaatan. Dalam S.Partohardjono dan M. Syam (eds) Pengembangan Terpadu Pertanian Lahan Pasang Surut dan Lebak. Risalah Pertemuan Nasional Pengembangan Pertanian Lahan Pasang Surut dan Rawa, Cisarua, 3-4 Maret. Puslitbangtan Bogor. 